\title{
Emerging and re-emerging infectious diseases: challenges and opportunities for militaries
}

\author{
Zheng Jie Marc Ho*, Yi Fu Jeff Hwang and Jian Ming Vernon Lee
}

\begin{abstract}
The communal nature of living and training environments, alongside suboptimal hygiene and stressors in the field, place military personnel at higher risk of contracting emerging infectious diseases. Some of these diseases spread quickly within ranks resulting in large outbreaks, and personnel deployed are also often immunologically naïve to otherwise uncommonly-encountered pathogens. Furthermore, the chance of weaponised biological agents being used in conventional warfare or otherwise remains a very real, albeit often veiled, threat. However, such challenges also provide opportunities for the advancement of preventive and therapeutic military medicine, some of which have been later adopted in civilian settings. Some of these include improved surveillance, new vaccines and drugs, better public health interventions and inter-agency co-operations. The legacy of successes in dealing with infectious diseases is a reminder of the importance in sustaining efforts aimed at ensuring a safer environment for both military and the community at large.
\end{abstract}

Keywords: Communicable diseases, Emerging, Infectious disease medicine, Military personnel

\section{Introduction}

Emerging and re-emerging infectious diseases are threats that military organisations have to guard against, as they cause substantial impact to operations and training. These diseases may arise from within the military community, as spill-over from the surrounding civilian populace, or during military operations and deployments. Biological warfare and bioterrorism are additional possibilities that militaries need to be prepared for.

Since historical times, emerging infectious diseases have impacted militaries, from the Plague of Athens in $430 \mathrm{BC}$ during the Peloponnesian War linked to the poisoning of water reservoirs by the Spartans [1], and the similar Antonine Plague in 166 AD brought back by returning Roman soldiers from the Parthian War [2,3]. The Thirty Years War from 1618 to 1648 also saw the devastating effects of Typhus (alongside Plague and accompanying starvation) which resulted in 10 million deaths [4], overshadowing 350,000 combat deaths. The weaponisation of naturally occurring diseases, the threat wrought by travelling soldiers returning home with novel diseases, and the disproportionate impact of disease and non-battle

\footnotetext{
* Correspondence: marchozj@gmail.com

Biodefence Centre, Headquarters of the Medical Corps, Singapore Armed Forces, 701 Transit Road, \#04-01, Singapore 778910, Singapore
}

injuries (DNBIs) are still relevant to militaries of today. In more recent times, there have been outbreaks reported among military personnel in both peacetime and field deployments. These include a peacetime Salmonella outbreak in a military establishment in India in 2011 due to possible contamination of food [5], the 2013 scabies outbreak among the Queen's Guards in the United Kingdom after a military exercise in Germany [6], and travellers' diarrhoea among U.S. military troops deployed during a training and humanitarian mission in $\mathrm{El}$ Salvador in 2011 [7].

Deployment of militaries to foreign grounds also exposes troops to local endemic diseases. A classic example of this is malaria. During World War II and the Vietnam War, 124,109 and 24,606 respective cases among U.S. military personnel deployed to the Southwest Pacific and Vietnam were reported $[8,9]$. Such infectious diseases have been shown to impact militaries significantly, not only in mortality and morbidity, but also in operational readiness. Even training during peacetime is affected by disease outbreaks, sometimes resulting in the unexpected suspension of military operations [10].

Unlike civilian settings, the military may acquire emerging and re-emerging infectious diseases from a myriad of origins and these often spread more readily, posing 
unique challenges to their prevention and control. At the same time, the frequency and extent of outbreaks in military settings provide opportunities to understand these diseases, and to develop new strategies (Figure 1). This review discusses some of the challenges militaries face from infectious diseases, as well as the societal benefits that militaries have brought to the world as these diseases are managed.

\section{Challenges in the military environment}

\section{Ease of disease transmission within military settings}

Many diseases, especially airborne, food and water borne, as well as vector borne diseases have been shown to spread readily in the military due to the close communal living and training quarters, operational constraints, and unique field hygiene conditions. Harsh environments, physical exertion and sleep deprivation, inadequate hygiene and sanitation, and psychological stress all result in physiological and immunological changes [11]. Although militaries comprise mostly young adults who are physically and mentally fitter, the above factors place them at unusually higher risks of infection.

As a result, there have been numerous reports of infectious disease outbreaks in military settings. These include, but are not limited to, gastroenteritis (particularly Norwalk-like/norovirus outbreaks) [12-14], acute respiratory infections (including influenza) [15-17] and conjunctivitis (particularly due to adenovirus) [18-20]. One report documented that US military trainees staying in a 60 person barracks were more susceptible to contracting acute respiratory infections than those in 8 person rooms, and that the risk was higher during the first few weeks of training before declining to baseline [21]. Similarly, ease of transmission due to close living quarters resulted in an Influenza A(H1N1) pdm09 outbreak in a Swiss military boot camp in 2010 involving 105 of 750 recruits [16]. These incidences reflect the need for preventive measures to protect against future incidences.

\section{Transmission between military and the community}

Some outbreaks in military settings are linked to an increased incidence of disease in the local civilian population. Although the extent of interactions between military and civilian elements vary across militaries, some mixing is inevitable either during transit of personnel from one setting to another, or through socio-civic duties such as disaster relief or community programs.

Amongst the many examples, a Hepatitis A outbreak from 1976 to 1977 in a U.S. military was linked to a nearby childcare facility [22], and concurrent civilian and military outbreaks of Human Adenovirus type 14 in Texas and Oregon in 2007 had possible civilian epidemiological links [23]. There were also reports of concurrent outbreaks of disease in both community and military settings during the outbreaks of enteroviral conjunctivitis in Singapore in 2005 [24] and mumps in Luxembourg in 2008 [25]. Significantly, both of these outbreaks occurred in small countries with military camps in close proximity to the population where increased opportunities for mixing occur.

\section{Infection during deployments}

Military deployments are commonplace in this age of globalisation and international co-operation, and this coincides with the fact that infectious diseases cross borders more frequently than ever before. Field and rural deployments place personnel at risk of new pathogens not normally encountered. As early as the First World War, the return of military forces from deployments to the trenches of Europe was suspected to have played a role in

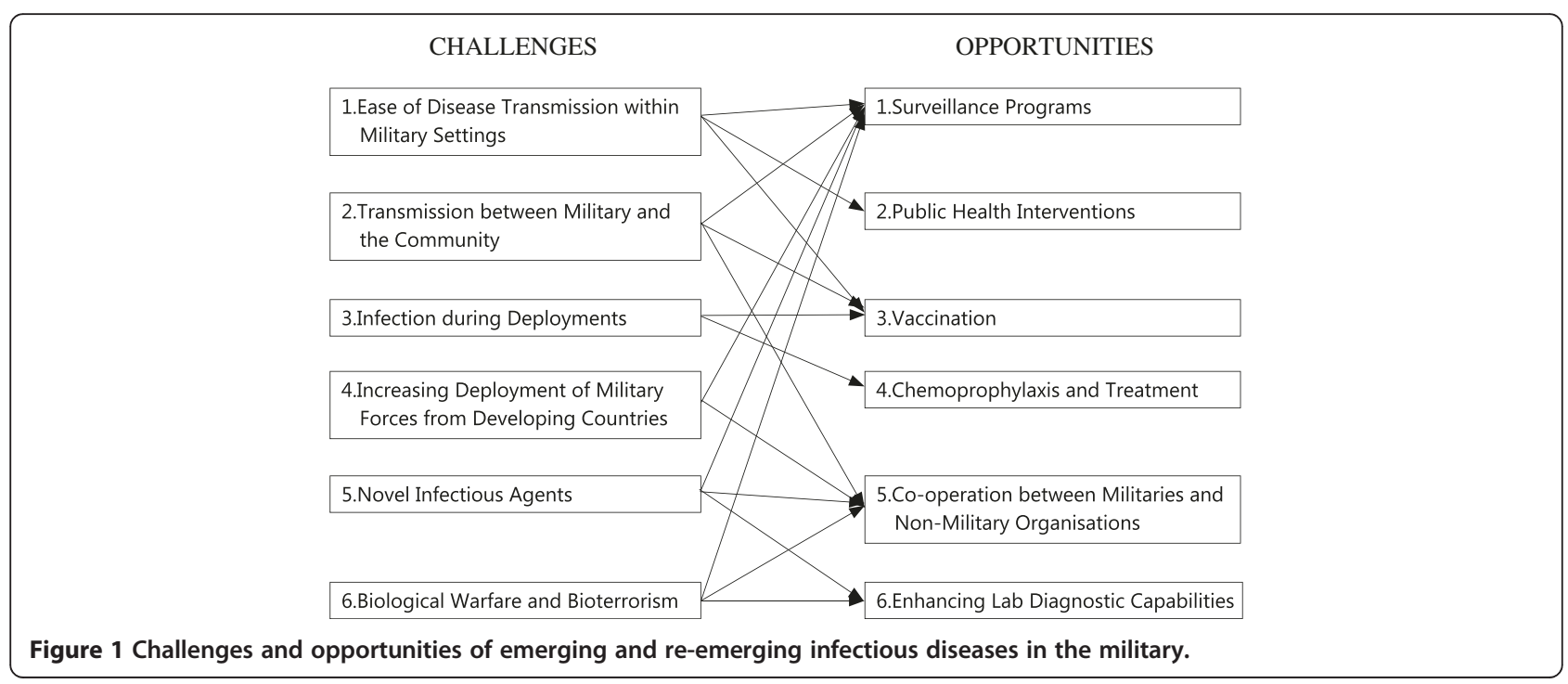


the rapid spread of the 1918/19 influenza pandemic [26]. More recently, 11 gastroenteritis outbreaks (10 caused by viruses) among British troops deployed overseas from 2002 to 2007 were documented [27]. Personnel returning to Australia from East Timor were also later diagnosed as having been infected with dengue from 1999 to 2000 [28], as did US servicemen infected with the malaria parasite in Iraq, Afghanistan and Korea from 2003 to 2005 [29]. Table 1 shows a selection of infectious diseases during more recent major military deployments and measures implemented (See also Figure 2). Many of these were ground breaking for their time, and provided evidence for their routine use today.

The French Armed Forces reported that from 1999 to 2009 , the rate of food borne disease outbreaks was significantly higher in servicemen deployed overseas (2.4 outbreaks/100,000 in France vs. 26.7 outbreaks/ 100,000 overseas). These were attributed to a lack of hygiene in operations and the consumption of unsafe local food [62]. Likewise, more than one-half of the 865 infectious diarrhoeal outbreaks in the Israeli military from 1988 to 2002 were in field units [63]. Diseases also tend to spread more efficiently during deployments, as seen by the development of four outbreaks of Norwalk-like viruses on board US Navy aircraft carriers from 1992 to 1997 which were attributed to crowding [50].

Military personnel are often also involved in disaster management, where they interact with displaced populations, themselves at risk of infectious diseases [64]. Water storage or stagnant water around temporary dwellings promotes breeding of vectors, made worse by the absence or interruption of vector control programmes. Furthermore, local food and water safety is poorly enforced, as is the spread of respiratory pathogens when military personnel interact with the local population. Vaccinations, chemoprophylaxis and personal hygiene measures are therefore critical in ensuring force protection when militaries deploy to these areas.

\section{Increasing deployment of military forces from developing countries}

Even developing country militaries that may not possess sophisticated public health capabilities are able to utilise many of the low cost disease prevention measures aforementioned. Some of these forces also double-up as health services for civilians in remote areas, reporting surveillance data to local health authorities, and contributing to national infectious disease surveillance [26]. Militaries also provide surge capacity during natural or man-made disasters when civilian resources are overwhelmed. There has also been an increase in number of developing countries contributing troops for multinational operations [26], and common standards of disease control should be applied to multilateral forces for collective protection. This may entail the distribution of resources from higher-income countries.

\section{Novel infectious agents}

Novel infectious agents such as zoonotic transmission of avian influenza viruses and Middle East respiratory syndrome coronavirus (MERS-CoV) pose challenges in early detection and prevention strategies, including military personnel who reside in or are deployed to affected areas. Returning travellers from affected areas also pose a threat and are difficult to screen if they visit these areas during personal leave. The impact of novel agents is shown by the effect of the 2009 pandemic H1N1 influenza on militaries from overseas importation or through the surrounding general population, with subsequent rapid spread in the closed living environments [65]. In addition, Dual Use Research of Concern (DURC) raises issues with regards to biosafety and biosecurity, such as that which involves the creation of laboratorymodified $\mathrm{H} 5 \mathrm{~N} 1$ viruses capable of respiratory transmission [66].

\section{Biological warfare and bioterrorism}

Biological agents have been used as weapons of war as early as 600 B.C., when cadavers and animal carcasses were used to weaken the enemy [67]. Blankets from smallpox patients were distributed by the British to Native Americans in 1763, and experiments involving various pathogens (including anthrax and meningococcus) were conducted by the Japanese biological warfare research program during World War II, the latter leading to numerous deaths [68]. Furthermore, biological agents can be utilised through unconventional means. The intentional contamination of salad bars in Oregon with Salmonella Typhimurium by the Rajneeshee cult in 1984 [69], the failed attempts to disperse botulinum toxin by the Japanese cult Aum Shinrikyo at various sites in Japan in the 1990s [70], and release of anthrax through mailed letters and packages in the U.S. in 2001 [71] are constant reminders of the ever present yet often concealed threat.

The need to protect against bioterrorism has thus emerged as a priority for most militaries. As bioterrorism can occur from the use of simple naturally occurring diseases to the development or theft of dangerous pathogens, it is important for militaries to prepare for and protect themselves against these threats. This includes the development of good diagnostic facilities for routine infectious diseases detection that also have the capability for detection of novel and dangerous pathogens. Laboratories (both military and civilian) should thus ensure the veracity of biosafety and biosecurity practices to prevent the occurrence of accidents or deliberate releases. This requires collaborations at the international level to strengthen global biosafety and biosecurity initiatives, and investments in 
Table 1 Infectious diseases during military deployments and measures implemented

\begin{tabular}{|c|c|c|c|}
\hline Operation & Year & Infectious diseases & Measures implemented \\
\hline American Civil War & 1861 to 1865 & Malaria [30] & Use of Quinine \\
\hline \multirow[t]{5}{*}{ World War I } & 1914 to 1918 & 1918 Influenza [31] & $\begin{array}{l}\text { Improvements in respiratory hygiene } \\
\text { and isolation }\end{array}$ \\
\hline & & Trench Foot [32] & Footwear modifications \\
\hline & & & $\begin{array}{l}\text { Foot protection (grease, borated talc } \\
\text { and camphor) }\end{array}$ \\
\hline & & & $\begin{array}{l}\text { Measures to improve trench and boot } \\
\text { drainage }\end{array}$ \\
\hline & & Tetanus [33] & $\begin{array}{l}\text { Prophylactic Anti-Tetanus serum to } \\
\text { wounded }\end{array}$ \\
\hline \multirow[t]{5}{*}{ World War II } & 1939 to 1945 & Wound infections $[34,35]$ & Use of Dakin's solution for antisepsis \\
\hline & & & Use of Sulfanilamide and Penicillin \\
\hline & & Scrub Typhus [36] & Development of delousing strategies \\
\hline & & Malaria [37] & Use of Atabrine \\
\hline & & Lymphatic Filariasis [38] & \\
\hline Korean War & 1950 to 1953 & $\begin{array}{l}\text { "Korean Haemorrhagic Fever" } \\
\text { (Hanta virus) [39] }\end{array}$ & $\begin{array}{l}\text { Improvement in environmental health } \\
\text { measures }\end{array}$ \\
\hline \multirow[t]{4}{*}{ Vietnam War } & 1953 to 1975 & Malaria and Dengue [40] & $\begin{array}{l}\text { Mosquito nets and repellents, Antimalarials } \\
\text { including Mefloquine - designed by army } \\
\text { to counter Chloroquine resistance. }\end{array}$ \\
\hline & & Bubonic Plague (Yersinia pestis) [41] & Flea insecticide and repellents \\
\hline & & & Immunisation with plague vaccines \\
\hline & & & $\begin{array}{l}\text { Protective clothing and Rat proofed } \\
\text { dwellings }\end{array}$ \\
\hline Persian Gulf War & 1990 to 1991 & $\begin{array}{l}\text { Preparedness against Biological } \\
\text { Warfare [42] }\end{array}$ & $\begin{array}{l}\text { Anthrax, Botulinum, Meningococcus } \\
\text { vaccines and Hepatitis A immunoglobulins }\end{array}$ \\
\hline Operation Restore Hope & 1993 & Malaria [43] & Use of Mefloquine and Doxycycline \\
\hline Operation Enduring & 2001 to 2011 & Leishmaniasis [44] & Genus specific probe for diagnosis \\
\hline $\begin{array}{l}\text { Freedom, Operation Iraqi } \\
\text { Freedom, Operation New }\end{array}$ & & & $\begin{array}{l}\text { Treatment modalities under investigational } \\
\text { new drug protocols }\end{array}$ \\
\hline \multirow[t]{7}{*}{ Dawn } & & & Better shelters and insect repellents \\
\hline & & Malaria [45] & $\begin{array}{l}\text { Use of rapid diagnostic assays and } \\
\text { Tafenoquine }\end{array}$ \\
\hline & & Norovirus and Shigella [46-48] & Use of rapid diagnostic assays \\
\hline & & & Segregation and enforcement of hygiene \\
\hline & & $\begin{array}{l}\text { Multidrug Resistant Wound } \\
\text { infections and Nosocomial }\end{array}$ & $\begin{array}{l}\text { Improvements in infection control } \\
\text { practices, antibiotic restriction policies }\end{array}$ \\
\hline & & Acinetobacter baumanii) [49] & $\begin{array}{l}\text { Admission surveillance cultures of } \\
\text { wounded soldiers and contact isolation }\end{array}$ \\
\hline & & & $\begin{array}{l}\text { Need for new antibiotics targeting } \\
\text { resistant Gram negative bacteria }\end{array}$ \\
\hline
\end{tabular}

capacity building at the local level, especially in settings of lower-resources.

\section{Opportunities for militaries}

Amidst these challenges, there are also multiple opportunities afforded for advancements in the prevention and control against infectious diseases in military settings, and history has shown how military medicine has risen to previous challenges.

\section{Surveillance programs}

Cross border spread and the emergence of novel pathogens have placed surveillance programs, such as that of the French Military Influenza Surveillance System (MISS) and the U.S. Armed Forces Health Surveillance Centre Global Emerging Infectious Surveillance and Response System (AFHSC-GEIS), as centrepieces in the early detection and warning of infectious diseases for the prompt implementation of mitigation and control measures. 


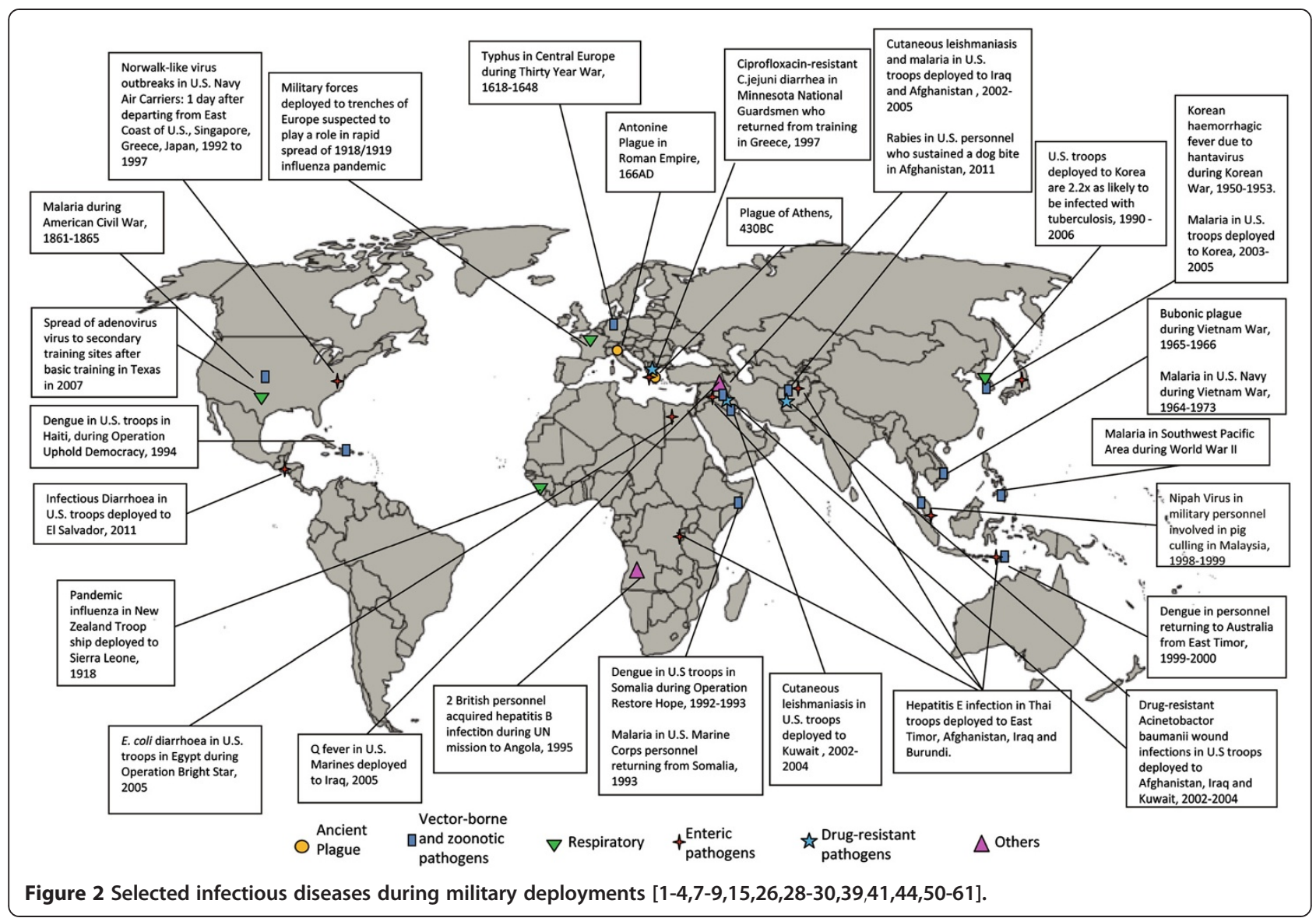

These surveillance systems are important for the global surveillance of infectious diseases. Through the US Naval Health Research Centre's surveillance program, Influenza A(H1N1)pdm09 in two California children was first identified, leading to the promulgation of an alert by the Centers for Disease Control and Prevention (CDC) [72]. This subsequently led to notification of another outbreak among New York students who had travelled to Mexico, and thereafter the detection of the same pathogen in outbreaks in Mexico [72]. These represented sentinel events leading to global awareness of the rapidly evolving situation.

Influenza surveillance can also be found in other armed forces, including the French who have participated in national surveillance through MISS since 1997. Its main objectives are the early detection of influenza outbreaks and monitoring of circulating viral strains [73]. Compared with national estimates, the MISS estimated lower amplitudes of influenza outbreaks in the military from 2008 to 2012, with possible reasons including younger ages, healthier personnel and compulsory influenza vaccination. In the Italian military, diseases such as measles and varicella are notifiable under its surveillance program
[74]. These results have been used to guide organisational vaccination policies. For example, after a tenfold increase in measles and fourfold increase in rubella from 1976-1980 to 1991-1995, mandatory MMR vaccination was instituted. Likewise, on noting that influenza was the foremost cause for febrile respiratory illnesses leading to substantial morbidity [75], the Singapore Armed Forces thereafter instituted annual influenza vaccination with significant success [76].

Military surveillance is often a component of wider population-wide protection measures, such as the Medical Surveillance System implemented in support of the United Nations Mission in Haiti [77]. The Peruvian Navy also developed an electronic disease surveillance to rapidly consolidate reportable diseases, thereby allowing earlier detection and control of disease outbreaks in the country. Finally, the Royal Thai Army instituted HIV screening on conscription, thereby serving as an indirect monitor of the national HIV situation [26,78].

\section{Public health interventions}

Public health interventions are equally as important in the management of infectious diseases in the military. 
These include contact precautions such as the disinfection of common living surfaces and hand hygiene, and droplet and airborne protection including isolating ill individuals and basic respiratory hygiene education. Food and water hygiene is also important due to the large numbers of individuals sharing common food and water sources. Some of these are more easily enforced in the controlled environments of military bases. However, once in the field, they pose a unique challenge where inadequate hygiene and sanitisation are often lacking. Even so, through innovations such as ready-to-eat meals and a host of water purification methods, militaries attempt to reduce these risks.

Positive examples of successful public health measures include the early identification and isolation of patients during the 1918 influenza pandemic which lowered attack rates in closed settings [79], and enhanced public health measures put in place for critical operations units in the Singapore military during the Influenza $\mathrm{A}(\mathrm{H} 1 \mathrm{~N} 1)$ pdm09 pandemic (including symptom monitoring and segregation into smaller subgroups when working) resulting in lower seroconversion rates (17\% vs. $44 \%$ for other units) [80]. Likewise, a study involving conjunctivitis outbreaks in a military camp showed that for each day to which control measures were delayed, the outbreak itself was extended by 0.82 days [81].

Health education also plays an important role amongst military personnel. This includes basic concepts such as disease recognition and prevention strategies, food hygiene and handwashing, respiratory hygiene, cleaning of common areas, and monitoring for disease symptoms. In addition, select personnel can be further trained in the use of personal protective equipment which range from simple gloves and masks during cleaning of soilages, to full suits against biological attacks.

vAnother area of interest is the use of public health measures for the prevention and containment of infection, especially regarding resistant bacteria in the combat wounded [82]. Environmental studies in military hospitals indicate the presence of nosocomial transmission of multi-drug resistant pathogens and/or existing colonisation prior to injury [83]. These led to the step-up of education predeployment, standardisation and enhancement of infection control measures, improved electronic support, and admission screening for resistant bacteria colonisation [49]. In a separate study, the conduct of a 5-day infection control course also showed a $21 \%$ improvement in knowledge [84].

Further epidemiological, public health and translational research provide opportunities for future advancements and better interventions to prevent further spread and quick containment of infectious diseases.

\section{Vaccination}

Since the time George Washington ordered the Continental army recruits to be vaccinated with smallpox vaccines in 1777 in response to outbreaks of variola, vaccination has evolved to become an integral part of troop protection against infections [85]. The military has also contributed to the development of many of these vaccines. For instance, the first typhoid vaccine produced for national supply was by the US Army Medical School in 1909, based on British and German production methods. The first inactivated influenza and adenovirus vaccines [86] were also developed by the US military, becoming the first iterations of the vaccines used today. Furthermore, military sponsored research contributed to the eventual licensure of ten vaccines from 1945 to 1955 [87]. Table 2 summarises the role to which militaries have played in the development of vaccines

Vaccines continue to be under development through military sponsored studies. For instance, a Phase 3 trial on an oral adenovirus Type 4 and 7 vaccine was conducted among US Military recruits [90], with subsequent FDA approval in 2011. Continued research into vaccines against dengue, norovirus and HIV continue to be much anticipated by both military and non-military medical communities.

Militaries across the world have developed their own vaccination programs that are often more comprehensive than their respective civilian populations. The U.S. military has routine immunisation for infectious diseases influenza and adenovirus, and travel immunisation depending on exposure, such as variola vaccination for personnel in areas at higher risk for release of smallpox as a weapon [91]. This being so, a World Health Organisation Survey in the 1990s noted that while $90 \%$ of the 52 militaries surveyed claimed to have compulsory military immunisation schedules, compulsory vaccination for different infectious diseases varies across militaries from 19\% for Measles, Mumps and Rubella to $87 \%$ for tetanus [92].

\section{Chemoprophylaxis and treatment}

The use of chemoprophylaxis and treatment against infections in the military continues to be an extensive field with opportunities for further exploration. During the American Civil War from 1861 to 1865, three studies on antiseptics (bromide, turpentine and nitric acid) showed reductions in mortality from hospital gangrene [93]. Almost 80 years later during the Second World War, the critical discovery of penicillin's antibiotic effects propelled it to become second highest priority (behind the atomic bomb) by the U.S. War Production Board [94]. Its use has often been cited as pivotal to success of the Allied Forces [95].

Apart from antibiotics, military medicine has also helmed developments and innovations in the use of anti-parasitic and anti-viral chemoprophylaxis. The anti-malarial drug mefloquine was developed by the Walter Reed Army Institute in the 1960s, in collaboration with the World 
Table 2 Vaccinations and military contributions [85-89]

\begin{tabular}{|c|c|c|}
\hline Vaccine & Year initiated & Military role \\
\hline Smallpox & 1777 & $\begin{array}{l}\text { Used by the Continental Army in 1777; Used by Prussian Army } \\
\text { during the Franco-Prussian War in } 1870\end{array}$ \\
\hline Yellow fever & 1900 & Demonstration of etiological agent and vector \\
\hline Typhoid fever & 1909 & $\begin{array}{l}\text { British Army used early forms during the Anglo-Boer War; US } \\
\text { Military developed killed typhoid vaccine for US Army and } \\
\text { Navy personnel }\end{array}$ \\
\hline Tetanus & 1940 & $\begin{array}{l}\text { Used by the US Army and Navy from 1940; Used by the } \\
\text { Luftwaffe in World War II }\end{array}$ \\
\hline Cholera & 1940,1980 s & $\begin{array}{l}\text { Injectable whole cell vaccines given to alert US Military Units } \\
\text { until } 1973\end{array}$ \\
\hline Hepatitis A & 1945,1985 & $\begin{array}{l}\text { US Military developed immunoglobulins and used in Korea and } \\
\text { Vietnam in the 1960s; US Military supported safety, immunogenicity } \\
\text { and efficacy studies }\end{array}$ \\
\hline Pneumococcus & 1945 & US Military tested first multivalent polysaccharide vaccine \\
\hline Diphtheria & $1950 \mathrm{~s}$ & US Military sponsored reduced dose formulation \\
\hline Anthrax & $1950 \mathrm{~s}$ & $\begin{array}{l}\text { Early anthrax vaccines were developed by Dr George Wright of } \\
\text { the U.S. Chemical Corps and his colleagues, and were licensed } \\
\text { in } 1970 \text {. }\end{array}$ \\
\hline Adenovirus & 1952-1969 & US Military developed killed bivalent and oral attenuated vaccine \\
\hline Influenza & 1957 & $\begin{array}{l}\text { US Military developed first iterations of influenza vaccines and } \\
\text { conducted trials among US service members }\end{array}$ \\
\hline Japanese Encephalitis & $1950 \mathrm{~s}, 1980 \mathrm{~s}$ & $\begin{array}{l}\text { US Military performed vaccination efforts in World War II and later } \\
\text { supported inactivated vaccine studies }\end{array}$ \\
\hline Plague & $1960 \mathrm{~s}$ & $\begin{array}{l}\text { US personnel in Vietnam and Southern Vietnam soldiers vaccinated } \\
\text { in the 1960s }\end{array}$ \\
\hline Meningococcus & 1968 & $\begin{array}{l}\text { US Military developed polysaccharide vaccine and supported clinical } \\
\text { trials; Adopted by the Israeli Army in } 1994\end{array}$ \\
\hline Rubella & 1972 & $\begin{array}{l}\text { US Military developed technique for isolating virus used to develop } \\
\text { the vaccine }\end{array}$ \\
\hline Measles & 1980 & US Military provided funding for development of an attenuated vaccine \\
\hline
\end{tabular}

Health Organisation and Hoffman-LaRoche [96]. Further studies also showed synergism between atovaquone and proguanil, with subsequent co-administration trials conducted at various sites by military-associated laboratories in Kenya, Brazil and Indonesia. The Influenza A(H1N1) pdm09 pandemic also saw the effective use of oseltamivir ring prophylaxis in the Singapore Military in localised outbreaks to bring about significant reductions in the reproductive number (the number of new cases attributable to the index case) from 1.91 to 0.11 , with significantly reduced rates of infection [97].

Other drugs have been, or are being evaluated for possible benefits of chemoprophylaxis in the military setting. These include the successful use of rifaximin for the prevention of travellers' diarrhoea among travellers and deployed military personnel [98], and dilute Dakin solution for angioinvasive fungal infection in the combat wounded [99].

Militaries around the world have also implemented chemoprophylaxis programs against specific threats. The U.S. military has guidelines for different infectious diseases including pre-exposure prophylaxis for malaria during deployments to affected areas and post-exposure prophylaxis for anthrax and meningococcus exposure [91]. The Republic of Korea Army instituted a malaria prophylaxis program in 1997, and no malaria deaths have been reported since [100]. In Singapore, malaria prophylaxis is routinely used for travel to malarious locations globally. At the same time, on Singapore's Tekong Island which houses a military training facility, an integrated combination malaria eradication strategy since 2006 has negated the need for malaria prophylaxis [101].

\section{Co-operation between militaries and Non-military organisations}

Collaborations between different militaries, as well as between militaries and civilian organisations on various levels are important in the prevention and control of infectious disease, and are best performed before the onset of outbreaks or epidemics. On a national level, the interface between the Peruvian military and Royal Thai Army (described earlier) with their respective national 
health networks allowed for smoother sharing of valuable information, so as to formulate more appropriate responses and measures where necessary [78]. On a larger scale, international networks allow participating countries to pool resources, providing greater equity. For example, the AFHSC-GEIS network picked up 76 outbreaks in 53 countries from 2008 to 2009, and involved supporting civilian entities in $48 \%$ of outbreak investigations, including a number of WHO regional reference laboratories [102].

Civil-military collaborations also play an important role during humanitarian efforts. After the earthquake in Haiti in 2010, security established by the military allowed civilian medical personnel more ready access to patients, and also provided critical equipment and supplies [103]. The Oslo Guidelines, updated by United Nations in 2007, provides guidelines for international military aid in disaster relief operations- one key point being that military assets should only be utilised when there are no viable alternatives, and with due regard for the sovereignty and leading role of local authorities [104,105].

\section{Enhancing lab diagnostic capabilities}

As early detection plays an important role in the mitigation of infectious diseases, militaries have a responsibility to enhance their laboratory capabilities for diagnosis. To maximise the use of resources, militaries should work together with civilian laboratories to strengthen national capabilities in the detection of novel infectious agents under International Health Regulations, exemplified by the early detection of Influenza A(H1N1)pdm09 by a U.S. military laboratory [72]. In addition, militaries sometimes require rapid diagnosis of common diseases especially during field deployments where full laboratory facilities may be unavailable. Enhancing laboratory capacity in militaries should therefore extend to improving capabilities in field and austere conditions where diseases are often encountered.

\section{Conclusion}

Although the ever-changing infectious diseases scene and harsh operational and training environment pose unique and sometimes seemingly daunting challenges to military organisations, it also presents many opportunities for scientific advancements in the areas of prevention, mitigation and control. From surveillance to treatment and public health measures, the field of infectious diseases in the military has, more than ever before, many puzzles waiting to be solved. Military healthcare providers and administrators involved in this worthwhile endeavour should also be encouraged that the work they do goes beyond accruing direct benefits for militaries, often flowing to the greater community at large. As such, continued investment in military surveillance, research and management of infectious diseases is important to ensure that the world we live in is safer from the threat of diseases.

\section{Competing interests}

The author(s) declare that they have no competing interests.

\section{Authors' contributions}

HZJ and HYF reviewed articles and drafted the manuscript. LJM conceptualised the review, participated in its design and reviewed the manuscript. All authors read and approved the final manuscript.

\section{Authors' information}

All authors are from the Biodefence Centre, Headquarters of the Medical Corps, Singapore Armed Forces. LJM (MBBS, PhD, MPH, MBA) is Head of the Centre, Associate Professor at Saw Swee Hock School of Public Health, National University of Singapore, and Visiting Consultant at the Ministry of Health, Singapore and Communicable Disease Centre, Singapore.

Received: 14 May 2014 Accepted: 7 August 2014

Published: 24 September 2014

\section{References}

1. Papagrigorakis MJ, Synodinos PN, Stathi A, Skevaki CL, Zachariadou L: The plague of Athens: an ancient act of bioterrorism? Biosecur Bioterror 2013, 11(3):228-229.

2. Fears JR: The plague under Marcus Aurelius and the decline and fall of the Roman Empire. Infect Dis Clin North Am 2004, 18(1):65-77.

3. Sabbatani S, Fiorino S: The antonine plague and the decline of the Roman Empire. Infez Med 2009, 17(4):261-275.

4. Conlon JM: The historical impact of epidemic typhus. http://entomology montana.edu/historybug/typhus-conlon.pdf. Last accessed 29 Jun 2014.

5. Kunwar $R$, Singh $H$, Mangla $V$, Hiremath R: Outbreak investigation: salmonella food poisoning. Med J Armed Forces India 2013, 69(4):388-391.

6. Nichol M: Queen's guards invaded... by a scabies outbreak: military exercises in Germany blamed as dozens are hit by skin disease. http:// www.dailymail.co.uk/news/article-2305038/Queens-Guards-invaded-scabiesoutbreak-Military-exercises-Germany-blamed-dozens-hit-skin-disease.html. Last accessed 30 Jun 2014.

7. Kasper MR, Lescano AG, Lucas C, Gilles D, Biese BJ, Stolovitz G, Reaves EJ: Diarrhea outbreak during U.S. military training in El Salvador. PLOS One 2012, 7(7):e40404.

8. Hart TA, Hardenbergh WH: The southwest pacific area. Preventive medicine in world War II, volume VI: communicable diseases: malaria. Chapter 10. http://history.amedd.army.mil/booksdocs/wwii/Malaria/tables/ table 79.pdf. (Last accessed 15 Apr 14).

9. Beadle C, Hoffman SL: History of malaria in the United States naval forces at war: World War I through the Vietnam conflict. Clin Infect Dis 1993, 16(2):320-329.

10. Smallman-Raynor MR, Cliff AD: Impact of infectious diseases on war. Infect Dis Clin North Am 2004, 18(2):341-368.

11. Korzeniewski K, Nitsch-Osuch A, Chciałowski A, Korsak J: Environmental factors, immune changes and respiratory diseases in troops during military activities. Respir Physiol Neurobiol 2013, 187(1):118-122.

12. Arness MK, Feighner BH, Canham ML, Taylor DN, Monroe SS, Cieslak TJ, Hoedebecke EL, Polyak CS, Cuthie JC, Fankhauser RL, Humphrey CD, Barker $\mathrm{TL}$, Jenkins CD, Skillman DR: Norwalk-like viral gastroenteritis outbreak in U.S. Army trainees. Emerg Infect Dis 2000, 6(2):204-207.

13. Grotto I, Huerta M, Balicer RD, Halperin T, Cohen D, Orr N, Gdalevich M: An outbreak of norovirus gastroenteritis on an Israeli military base. Infection 2004, 32(6):339-343.

14. Yap J, Qadir A, Liu I, Loh J, Tan BH, Lee VJ: Outbreak of acute norovirus gastroenteritis in a military facility in Singapore: a public health perspective. Singapore Med J 2012, 53(4):249-254.

15. Summers JA: Pandemic influenza outbreak on a troop ship-diary of a soldier in 1918. Emerg Infect Dis 2012, 18(11):1900-1903.

16. Jeger V, Dünki A, Germann M, Fux CA, Faas A, Exadaktylos AK, Stettbacher A: H1N1 outbreak in a Swiss military boot camp-observations and suggestions. Swiss Med Wkly 2011, 141:w13307.

17. Cosby MT, Pimentel G, Nevin RL, Fouad Ahmed S, Klena JD, Amir E, Younan M, Browning R, Sebeny PJ: Outbreak of H3N2 influenza at a US military 
base in Djibouti during the H1N1 pandemic of 2009. PLoS One 2013, 8(12):e82089.

18. Majeed A, Naeem Z, Khan DA, Ayaz A: Epidemic adenoviral conjunctivitis report of an outbreak in a military garrison and recommendations for its management and prevention. J Pak Med Assoc 2005, 55(7):273-275

19. Paparello SF, Rickman LS, Mesbahi HN, Ward JB, Siojo LG, Hayes CG Epidemic keratoconjunctivitis at a U.S. military base: Republic of the Philippines. Mil Med 1991, 156(5):256-259.

20. Crum NF, Barrozo CP, Chapman FA, Ryan MA, Russell KL: An outbreak of conjunctivitis due to a novel unencapsulated streptococcus pneumoniae among military trainees. Clin Infect Dis 2004, 39(8):1148-1154.

21. White DW, Feigley CE, McKeown RE, Hout JJ, Hebert JR: Association between barracks type and acute respiratory infection in a gender integrated Army basic combat training population. Mil Med 2011, 176(8):909-914.

22. Benenson MW, Takafuji ET, Bancroft WH, Lemon SM, Callahan MC, Leach DA: A military community outbreak of hepatitis type a related to transmission in a child care facility. Am J Epidemiol 1980, 112(4):471-481.

23. Centers for Disease Control and Prevention (CDC): Acute respiratory disease associated with adenovirus serotype 14-four states, 2006-2007. MMWR Morb Mortal Wkly Rep 2007, 56(45):1181-1184

24. Ong AE, Dashraath $P$, Lee VJ: Management of enteroviral conjunctivitis outbreaks in the Singapore military in 2005. Southeast Asian J Trop Med Public Health 2008, 39(3):398-403.

25. Mossong J, Bonert C, Weicherding P, Opp M, Reichert P, Even J, Schneider F: Mumps outbreak among the military in Luxembourg in 2008: epidemiology and evaluation of control measures. Euro Surveill 2009, 14(7).

26. Chretien JP, Blazes DL, Coldren RL, Lewis MD, Gaywee J, Kana K, Sirisopana N, Vallejos V, Mundaca CC, Montano S, Martin GJ, Gaydos JC: The importance of militaries from developing countries in global infectious disease surveillance. Bull World Health Organ 2007, 85(3):174-180.

27. Bailey MS, Gallimore Cl, Lines LD, Green AD, Lopman BA, Gray JJ, Brown DW: Viral gastroenteritis outbreaks in deployed British troops during 2002-7. J R Army Med Corps 2008, 154(3):156-159.

28. Kitchener S, Leggat PA, Brennan L, McCall B: Importation of dengue by soldiers returning from east Timor to north Queensland, Australia. J Travel Med 2002, 9(4):180-183.

29. Ciminera P, Brundage J: Malaria in U.S. Military forces: a description of deployment exposures from 2003 through 2005. Am J Trop Med Hyg 2007, 76(2):275-279.

30. D'Amelio R, Molica C, Biselli R, Stroffolini T: Surveillance of infectious diseases in the Italian military as pre-requisite for tailored vaccination programme. Vaccine 2001, 19(15-16):2006-2011.

31. Seah SG, Lim EA, Kok-Yong S, Liaw JC, Lee V, Kammerer P, Metzgar D, Russell KL, Tan BH: Viral agents responsible for febrile respiratory illnesses among military recruits training in tropical Singapore. J Clin Virol 2010, 47(3):289-292.

32. Tan XQ, Zhao X, Lee VJ, Loh JP, Tan BH, Koh WH, Ng SH, Chen Ml, Cook AR: Respiratory viral pathogens among Singapore military servicemen 2009-2012: epidemiology and clinical characteristics. BMC Infect Dis 2014, 14(1):204.

33. Gambel JM, Drabick JJ, Martinez-Lopez L: Medical surveillance of multinational peacekeepers deployed in support of the United Nations mission in Haiti, June-October 1995. Int J Epidemiol 1999, 28(2):312-318.

34. Kana K, Tabprasit S, Chuenchitra T, Sirisopana N, Rangsin R: HIV-1 incidence estimates among young Thai men using lgG-capture BED-enzyme immunoassay (BED-CEIA) during 2005-2006. J Med Assoc Thai 2009, 92(Suppl 1):S112-S116.

35. Kiliç S, Gray GC: Nonpharmaceutical interventions for military populations during pandemic influenza. Turk Silahli Kurvetleri Koruyucu Hekim Bul 2007, 6(4):285-290.

36. Lee V, Yap J, Cook AR, Chen M, Tay J, Barr I, Kelso A, Tan B, Loh JP, Lin R, Cui L, Kelly PM, Leo Y, Chia K, Kang WL, Tambyah P, Seet B: Effectiveness of public health measures in mitigating pandemic influenza spread: a prospective sero-epidemiological cohort study. J Infect Dis 2010, 202(9):1319-1326.

37. Yeo DS, Seah SG, Chew JS, Lim EA, Liaw JC, Loh JP, Tan BH: Molecular Identification of coxackievirus A24 variant isolated from an outbreak of acute haemorrhagic conjunctivitis in Singapore in 2005. Arch Virol 2007, 152(11):2005-2016.

38. Hospenthal DR, Green AD, Crouch HK, English JF, Pool J, Yun HC, Murray CK, Prevention of Combat-Related Infections Guidelines Panel: Infection prevention and control in deployed military medical treatment facilities. J Trauma 2011, 71(2 Suppl 2):S290-S298.

39. Keen EF 3rd, Mende K, Yun HC, Aldous WK, Wallum TE, Guymon CH, Cole DW, Crouch HK, Griffith ME, Thompson BL, Rose JT, Murray CK: Evaluation of potential environmental contamination sources for the presence of multidrug-resistant bacteria linked to wound infections in combat casualties. Infect Control Hosp Epidemiol 2012, 33(9):905-911.

40. Crouch HK, Murray CK, Hospenthal DR: Development of a deployment infection control course. Mil Med 2010, 175(12):983-989.

41. Grabenstein JD, Pittman PR, Greenwood JT, Engler RJ: Immunization to protect the US armed forces: heritage, current practice, and prospects. Epidemiol Rev 2006, 28:3-26.

42. U.S. Military and vaccine history. http://history.amedd.army.mil/booksdocs/ wwii/Malaria/tables/table79.pdf.

43. Schmaljohn CS, Smith LA, Friedlander AM: Military vaccines in today's environment. Hum Vaccin Immunother 2012, 8(8):1126-1128.

44. Artenstein AW: Vaccines for military use. Vaccine 2009, 27(Suppl 4):D16-D22.

45. Mimouni D, Bar-Zeev Y, Huerta M, Balicer RD, Grotto I, Ankol O: Preventive effect of meningococcal vaccination in Israeli military recruits. Am J Infect Control 2010, 38(1):56-58.

46. Kuschner RA, Russell KL, Abuja M, Bauer KM, Faix DJ, Hait H, Henrick J, Jacobs M, Liss A, Lynch JA, Liu Q, Lyons AG, Malik M, Moon JE, Stubbs J, Sun W, Tang D, Towle AC, Walsh DS, Wilkerson D, Adenovirus Vaccine Efficacy Trial Consortium: A phase 3, randomized, double-blind, placebo-controlled study of the safety and efficacy of the live, oral adenovirus type 4 and type 7 vaccine, in U.S. military recruits. Vaccine 2013, 31(28):2963-2971.

47. Headquarters, Departments of the Army, the Navy, the Air Force, and the Coast Guard: Army regulation 40-562. Immunizations and chemoprophylaxis for the prevention of infectious diseases. 2013, http://www.apd.army.mil/pdffiles/ r40_562.pdf.

48. D'Amelio R, Heymann DL: Can the military contribute to global surveillance and control of infectious diseases? Emerg Infect Dis 1998, 4(4):704-705.

49. Mancuso JD, Tobler SK, Eick AA, Keep LW: Active tuberculosis and recent overseas deployment in the U.S. military. Am J Prev Med 2010, 39(2):157-163

50. Haller JS Jr: Trench foot-a study in military-medical responsiveness in the Great War, 1914-1918. West J Med 1990, 152(6):729-733.

51. Wainwright M: Hitler's penicillin. Perspect Biol Med 2004, 47(2):189-198. Spring.

52. Kitchen LW, Vaughn DW, Skillman DR: Role of US military research programs in the development of US food and drug administration-approved antimalarial drugs. Clin Infect Dis 2006, 43(1):67-71.

53. Lee VJ, Yap J, Cook AR, Chen MI, Tay JK, Tan BH, Loh JP, Chew SW, Koh WH, Lin R, Cui L, Lee CW, Sung WK, Wong CW, Hibberd ML, Kang WL, Seet B, Tambyah PA: Oseltamivir ring prophylaxis for containment of $2009 \mathrm{H} 1 \mathrm{~N} 1$ influenza outbreaks. N Engl J Med 2010, 362(23):2166-2174. doi: 10.1056/ NEJMoa0908482.

54. Armstrong AW, Ulukan S, Weiner M, Mostafa M, Shaheen H, Nakhla I, Tribble DR, Riddle MS: A randomized, double-blind, placebo-controlled study evaluating the efficacy and safety of rifaximin for the prevention of travelers' diarrhea in US military personnel deployed to incirlik air base, incirlik, turkey. J Travel Med 2010, 17(6):392-394.

55. Lewandowski L, Purcell R, Fleming M, Gordon WT: The use of dilute Dakin's solution for the treatment of angioinvasive fungal infection in the combat wounded: a case series. Mil Med 2013, 178(4):e503-e507.

56. Lee SO: Commencement of the meningococcal vaccination for the republic of Korea army. Infect Chemother 2013, 45(1):113-115.

57. Lee VJ, Ow S, Heah H, Tan MY, Lam P, Ng LC, Lam-Phua SG, Imran AQ, Seet B: Elimination of malaria risk through integrated combination strategies in a tropical military training island. Am J Trop Med Hyg 2010, 82(6):1024-1029.

58. Johns MC1, Burke RL, Vest KG, Fukuda M, Pavlin JA, Shrestha SK, Schnabel DC, Tobias S, Tjaden JA, Montgomery JM, Faix DJ, Duffy MR, Cooper MJ, Sanchez JL, Blazes DL, AFHSC-GEIS Outbreak Response Writing Group, Wangchuk S, Dorji T, Gibbons R, lamsirithaworn S, Richardson J, Buathong R, Jarman R, Yoon IK, Shakya G, Ofula V, Coldren R, Bulimo W, Sang R, Omariba $D$, et al: A growing global network's role in outbreak response: AFHSCGEIS 2008-2009. BMC Public Health 2011, 11(Suppl 2):S3.

59. Auerbach PS, Norris RL, Menon AS, Brown IP, Kuah S, Schwieger J, Kinyon J, Helderman TN, Lawry L: Civil-military collaboration in the initial medical response to the earthquake in Haiti. N Engl J Med 2010, 362(10):e32.

60. UN News Centre: UN updates guidelines for international military aid in disaster relief operations. Published 27 November 2006. http://www.un. 
org/apps/news/story.asp? NewsID=20733\#.VDCegfmSzuJ = 20733\#. Last accessed 13 July 2014

61. United Nations Office for the Coordination of Humanitarian Affairs: Oslo guidelines: guidelines on the Use of foreign military and civil defence assets in disaster relief. Revision 1.1 November 2007. http://www.refworld. org/pdfid/47da87822.pdf

62. Hasegawa GR: Quinine substitutes in the confederate army. Mil Med 2007, 172(6):650-655.

63. Ott M, Shaw SF, Danila RN, Lynfield R: Lessons learned from the 1918-1919 influenza pandemic in Minneapolis and St. Paul, Minnesota. Public Health Rep 2007, 122(6):803-810.

64. Wever $\mathrm{PC}$, van Bergen L: Prevention of tetanus during the First World War. Med Humanit 2012, 38(2):78-82.

65. Hirsch EF: "The treatment of infected wounds", Alexis Carrel's contribution to the care of wounded soldiers during world War 1. J Trauma 2008, 64(3 Suppl):S209-S210.

66. Shama G: Auntibiotics: the BBC, penicillin, and the second world war. BMJ 2008, 337:a2746.

67. Bavaro MF, Kelly DJ, Dasch GA, Hale BR, Olson P: History of U.S. Military contributions to the study of rickettsial diseases. Mil Med 2005, 170(4 Suppl):49-60.

68. Weina PJ: From atabrine in World War II to mefloquine in Somalia: the role of education in preventive medicine. Mil Med 1998, 163(9):635-639.

69. Leggat PA, Melrose W: Lymphatic filariasis: disease outbreaks in military deployments from World War II. Mil Med 2005, 170(7):585-589.

70. Marshall RC, Rhodes CB: Korean hemorrhagic fever: environmental health and medical surveillance measures. Mil Med 1990, 155(12):607-610.

71. Gibbons RV, Streitz M, Babina T, Fried JR: Dengue and US military operations from the Spanish-American War through today. Emerg Infect Dis 2012, 18(4):623-630.

72. Marshall JD Jr, Joy RJ, Ai NV, Quy DV, Stockard JL, Gibson FL: Plague in Vietnam 1965-1966. Am J Epidemiol 1967, 86(2):603-616

73. Hyams KC, Riddle J, Trump DH, Graham JT: Endemic infectious diseases and biological warfare during the Gulf War: a decade of analysis and final concerns. Am J Trop Med Hyg 2001, 65(5):664-670.

74. Wallace MR, Sharp TW, Smoak B, lriye C, Rozmajzl P, Thornton SA, Batchelor R, Magill AJ, Lobel HO, Longer CF, Burans JP: Malaria among United States troops in Somalia. Am J Med 1996, 100(1):49-55.

75. Zapor MJ, Moran KA: Infectious diseases during wartime. Curr Opin Infect Dis 2005, 18(5):395-399.

76. Coleman RE, Hochberg LP, Putnam JL, Swanson KI, Lee JS, MCAvin JC, Chan AS, Oguinn ML, Ryan JR, Wirtz RA, Moulton JK, Dave K, Faulde MK: Use of vector diagnostics during military deployments: recent experience in Iraq and Afghanistan. Mil Med 2009, 174(9):904-920.

77. Aronson NE, Sanders JW, Moran KA: In harm's way: infections in deployed American military forces. Clin Infect Dis 2006, 43(8):1045-1051. Epub 2006 Sep 14.

78. Thornton SA, Sherman SS, Farkas T, Zhong W, Torres P, Jiang X: Gastroenteritis in US marines during operation Iraqi freedom. Gastroenteritis in US marines during operation Iraqi freedom. Clin Infect Dis 2005, 40(4):519-525.

79. Centers for Disease Control and Prevention (CDC): Outbreak of acute gastroenteritis associated with Norwalk-like viruses among British military personnel-Afghanistan, May 2002. MMWR Morb Mortal Wkly Rep 2002, 51(22):477-479.

80. Hospenthal DR, Crouch HK, English JF, Leach F, Pool J, Conger NG, Whitman TJ, Wortmann GW, Murray CK, Cordts PR, Gamble WB: Response to infection control challenges in the deployed setting: operations Iraqi and enduring freedom. J Trauma 2010, 69(Suppl 1):S94-S101.

81. McCarthy M, Estes MK, Hyams KC: Norwalk-like virus infection in military forces: epidemic potential, sporadic disease, and the future direction of prevention and control efforts. J Infect Dis 2000, 181(Suppl 2):S387-S391.

82. Trofa AF, DeFraites RF, Smoak BL, Kanesa-thasan N, King AD, Burrous JM, MacArthy PO, Rossi C, Hoke CH Jr: Dengue fever in US military personnel in Haiti. JAMA 1997, 277(19):1546-1548.

83. Sharp TW, Wallace MR, Hayes CG, Sanchez JL, DeFraites RF, Arthur RR, Thornton SA, Batchelor RA, Rozmajzl PJ, Hanson RK, Wu SJ, Iriye C, Burans JP: Dengue fever in U.S. Troops during operation restore hope, Somalia, 1992-1993. Am J Trop Med Hyg 1995, 53(1):89-94.

84. Croft AM, Ollerton JE, Fear NT: Hepatitis B infection following deployment to Angola. J R Nav Med Serv 2008, 94(3):108-111.
85. Myint KS, Duripunt P, Mammen MP Jr, Sirisopana N, Rodkvamtook W, Gibbons RV: Hepatitis E virus infection in Thai troops deployed with U.N. peacekeeping forces. Mil Med 2007, 172(11):1217-1219.

86. Riddle MS, Halvorson HA, Shiau D, Althoff J, Monteville MR, Shaheen H, Horvath $E P$, Armstrong AW: Acute gastrointestinal infection, respiratory illness, and noncombat injury among US military personnel during operation bright star 2005, in northern Egypt. J Travel Med 2007, 14(6):392-401.

87. Newton JA Jr, Schnepf GA, Wallace MR, Lobel HO, Kennedy CA, Oldfield EC 3rd: Malaria in US marines returning from Somalia. JAMA 1994, 272(5):397-399.

88. Trunkey DD: History and development of trauma care in the United States. Clin Orthop Relat Res 2000, 374:36-46.

89. Brodie B: The search for penicillin. Windows Time 2004, 12(2):6-11.

90. Centers for Disease Control and Prevention (CDC): Imported human rabies in a U.S. Army soldier - New York, 2011. MMWR Morb Mortal Wkly Rep 2012, 61(17):302-305.

91. Faix DJ, Harrison DJ, Riddle MS, Vaughn AF, Yingst SL, Earhart K, Thibault G: Outbreak of Q fever among US military in western Iraq, June-July 2005. Clin Infect Dis 2008, 46(7):e65-e68.

92. Trei JS, Johns NM, Garner JL, Noel LB, Ortman BV, Ensz KL, Johns MC, Bunning ML, Gaydos JC: Spread of adenovirus to geographically dispersed military installations, May-October 2007. Emerg Infect Dis 2010, 16(5):769-775.

93. Ali R, Mounts AW, Parashar UD, Sahani M, Lye MS, Isa MM, Balathevan K, Arif MT, Ksiazek TG: Nipah virus among military personnel involved in pig culling during an outbreak of encephalitis in Malaysia, 1998-1999. Emerg Infect Dis 2001, 7(4):759-761.

94. Mayet A, Manet G, Decam C, Morisson D, Bédubourg G, Pommier De Santi V, Meynard JB, Bornert G, Deparis X, Migliani R: Epidemiology of food-borne disease outbreaks in the French armed forces: a review of investigations conducted from 1999 to 2009. J Infect 2011, 63(5):370-374.

95. Schwaber MJ, Grotto I, Balicer RD, Davidovitch N, Zelikovitch Y, Huerta M: Infectious diarrheal outbreaks in the Israeli military, 1988-2002. Mil Med 2005, 170(7):634-637.

96. Wilder-Smith A: Tsunami in South Asia: what is the risk of post-disaster infectious disease outbreaks? Ann Acad Med Singapore 2005, 34(10):625-631.

97. Chen MI, Lee VJ, Lim WY, Barr IG, Lin RT, Koh GC, Yap J, Cui L, Cook AR, Laurie K, Tan LW, Tan BH, Loh J, Shaw R, Durrant C, Chow VT, Kelso A, Chia KS, Leo YS: 2009 influenza $A(\mathrm{H} 1 \mathrm{~N} 1)$ seroconversion rates and risk factors among distinct adult cohorts in Singapore. JAMA 2010, 303(14):1383-1391.

98. World Health Organisation: Report of the WHO informal consultation on dual Use research of concern. ; 2013.

99. Riedel S: Biological warfare and bioterrorism: a historical review. Proc (Bayl Univ Med Cent) 2004, 17(4):400-406.

100. Metcalfe N: A short history of biological warfare. Med Confl Surviv 2002, 18(3):271-282.

101. Jacobs MK: The history of biologic warfare and bioterrorism. Dermatol Clin 2004, 22(3):231-246.

102. Danzig R, Sageman M, Leighton T, Hough L, Yuki H, Kotani R, Hosford ZM: Aum shinrikyo: insights into how terrorists develop biological and chemical weapons. Centre for a New American Security; 2011.

103. Jernigan JA, Stephens DS, Ashford DA, Omenaca C, Topiel MS, Galbraith M, Tapper M, Fisk TL, Zaki S, Popovic T, Meyer RF, Quinn CP, Harper SA, Fridkin SK, Sejvar JJ, Shepard CW, McConnell M, Guarner J, Shieh WJ, Malecki JM, Gerberding JL, Hughes JM, Perkins BA, Anthrax Bioterrorism Investigation Team: Bioterrorism-related inhalational anthrax: the first 10 cases reported in the United States. Bioterrorism-related inhalational anthrax: the first 10 cases reported in the United States. Bioterrorism-related inhalational anthrax: the first 10 cases reported in the United States. Emerg Infect Dis 2001, 7(6):933-944.

104. Zhang Y, Lopez-Gatell H, Alpuche-Aranda CM, Stoto MA: Did advances in global surveillance and notification systems make a difference in the $2009 \mathrm{H} 1 \mathrm{~N} 1$ pandemic?-a retrospective analysis. PLoS One 2013, 8(4):e59893.

105. Duron S, Mayet A, Lienhard F, Haus-Cheymol R, Verret C, Védy S, Le Guen P, Berbineau L, Brisou P, Dubrous P, Garnotel E, Meynard JB, Deparis X, Mérens A, Bigaillon C, Migliani R, MISS staff: The French Military influenza surveillance system (MISS): overview of epidemiological and virological results during four influenza seasons-2008-2012. Swiss Med Wkly 2013, 143:w13848.

doi:10.1186/2054-9369-1-21

Cite this article as: Ho et al.: Emerging and re-emerging infectious diseases: challenges and opportunities for militaries. Military Medical Research 2014 1:21. 